COMPARISON OF FLOOD FREQUENCY ESTIMATES FROM SYNTHETIC AND OBSERVED DATA ON SMALL DRAINAGE AREAS IN MISSISSIPPI

by B. E. Colson

U. S. GEOLOGICAL SURVEY

Water-Resources Investigations Report 86-4034

Prepared in cooperation with the MISSISSIPPI STATE HIGHWAY DEPARTMENT

Jackson, Mississippi 


\section{UNITED STATES DEPARTMENT OF THE INTERIOR}

DONALD PAUL HODEL, SECRETARY

GEOLOGICAL SURVEY

Dallas L. Peck, Director

For additional information write to:

U.S. Geological Survey Water Resources Division

Suite 710 , Federal Building 100 W. Capitol Street Jackson, Mississippi 39269

Telephone: (601) 965-4600
Copies of this report can be purchased from:

Open-File Services Section Western Distribution Branch U.S. Geological Survey Box 25425, Federal Center Lakewood, Colorado 80225 Telephone: (303) 236-7476 
Abstract-_-_- 1

Introduction-_-_-_- 2

Flood-frequency analysis-_-_._-_._- 3

Analysis of observed data_- 5

Comparison of results-__-_ 5

Summary--_-_-_-_-_- 22

Selected references-_-_-_- 23

\section{ILLUSTRATIONS}

Figure 1. Map showing locations of gaging stations used for comparing observed and synthetic flood frequency---

2. Graph showing comparison of synthetic and observed 2-year flood discharge---

3. Graph showing comparison of synthetic and observed

4. Graph showing comparison of synthetic and observed

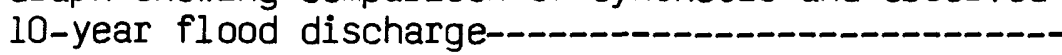

5. Graph showing comparison of synthetic and observed

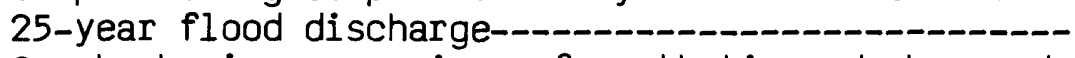

6. Graph showing comparison of synthetic and observed

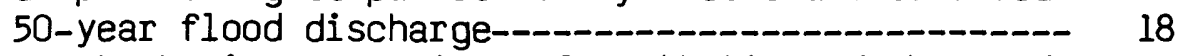

7. Graph showing comparison of synthetic and observed 100-year flood discharge---_--_--.-- 19

8. Flood frequency curves for selected gaging stations based on observed (measured) discharge data--.---- 20

9. Flood frequency curves for selected gaging stations

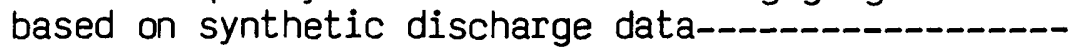

\section{TABLES}

Table 1.--Gaging stations and period of record----------------- 6

2.--Basin characteristics and comparison of observed

versus synthetic flood discharges-_. 


\section{ABBREVIATIONS AND CONVERSION FACTORS}

This report uses inch-pound units. The equivalent International System (SI) units bay be obtained using the following factors.

Multiply

foot ( ft)

mile (mi)

square mile $\left(\mathrm{mi}^{2}\right)$

cubic foot per second $\left(\mathrm{ft}^{3} / \mathrm{s}\right)$
By

0.3048

1.609

2.590

0.02832
To obtain

meter (m)

kilometer $(\mathrm{km})$

square kilometer $\left(\mathrm{km}^{2}\right)$ cubic meter per second $\left(\mathrm{m}^{3} / \mathrm{s}\right)$ 


\title{
COMPARISON OF FLOOD FREQUENCY ESTIMATES FROM SYNTHETIC AND OBSERVED DATA ON SMALL DRAINAGE AREAS IN MISSISSIPPI \\ by $B$. E. Colson
}

\begin{abstract}
In 1964 the U.S. Geological Survey in Mississippi expanded the small stream-gaging network for collection of rainfall and runoff data to 92 stations. To expedite availability of flood-frequency information a rainfall-runoff model using available long-term rainfall data was calibrated to synthesize flood peaks. Results obtained from observed annual peak flow data for 51 sites having 16 to 30 years of annual peaks are compared with the synthetic results. Graphical comparison of the 2, 5, 10, 25, 50, and 100-year flood discharges indicate good agreement. The root mean square error ranges from 27 to 38 percent and the synthetic record bias from -9 to -18 percent in comparison with the observed record. The reduced variance in the synthetic results is attributed to use of only four long-term rainfall records and model limitations. The root mean square error and bias is within the accuracy considered to be satisfactory.
\end{abstract}




\section{INTRODUCTION}

The U.S. Geological Survey and Mississippi State Highway Department have a long-standing cooperative program of water resources investigations, one element of which is the continuing investigation of the flood frequency of streams in Mississippi. About 1955 the Survey began the systematic collection of peak-flow data on small drainage areas in Mississippi. The early impetus was supplied by wide-spread flood damage to culverts and roadways from severe thunderstorm activity in Mississippi. These floods were in contrast to the severe regional drought that was experienced throughout the State during the mid 1950's.

In 1964 the U.S. Geological Survey entered into a nationwide program sponsored by the Federal Highway Administration to study flood frequency of small drainage areas. The Mississippi District of the U.S. Geological Survey, in cooperation with the State Highway Department expanded the small streamgaging network to a total of 95 sites to collect rainfall and runoff data. Gages were relocated or discontinued for various reasons resulting in fluctuations of the number of stations operated during the study.

During this time the nation was involved in a massive highway construction program which required hydraulic design of stream crossings. It was deemed undesirable to wait for the collection of long-term flood records on small streams for frequency analysis.

The U.S. Geological Survey developed a rainfall-runoff model (Dawdy, and others, 1972) to generate flood peaks using available long-term rainfall and evaporation data. The model was calibrated for each of the gaging sites by optimizing 10 basin parameters using concurrent precipitation, evaporation and runoff records. Each set of parameters was then used in the model with long-term climatic records collected by the National Weather Service at Meridian and Vicksburg, Miss., Memphis, Tenn., and New Orleans, La., and pan-evaporation data from Mississippi State University to generate synthetic flood records. These four synthetic records were composited for each site. The frequency analyses of these synthetic records were used in preparation of the statewide report, "Flood Frequency of Mississippi Streams" (Colson and Hudson, 1976). On completion of this report it was recommended that the small streams network be continued until at least 20 to 25 years of record was available to assess the validity of the synthetic flood-peak data. In 1977, a technique described by Moss and Karlinger (1974) was applied to the network. This analysis indicated that 80 percent of the information could be obtained from 45 sites chosen to represent a broad range of stream characteristics. The small basin gaging station network was reduced to 45 sites during 1977 . The reduced network was operated through the water year ending September 1984. The U.S. Geological Survey agreed to make a comparison of the synthetic data with results from observed data through 1984.

The Survey cooperative agreement with the Mississippi State Highway Department and the Federal Highway Administration provided for collec- 
tion of observed annual peak discharge at a number of sites to evaluate the reliability of the sythetic records. This report provides a comparison of the synthetic flood-frequency values used in the first report "Flood Requency of Mississippi Streams" and the values computed from observed annual peaks through the 1984 water year. Fifty-one sites having 16 years or longer record are used in this report for comparison with the synthetic results (fig. 1).

The adequacy of the rainfall-runoff model and the methods of analysis of the model, except in a general sense, are beyond the scope of this report.

\section{FLOOD-FREQUENCY ANALYSIS}

The synthetic values used in the 1976 report were computed from the annual peaks generated by using long-term rainfall and evaporation data in a calibrated model for each of 89 sites. This produced four sets of annual peak discharges at each gage site, based on evaporation data from Mississippi State University and on rainfall for Meridian and Vicksburg, Miss., Memphis, Tenn., and New Orleans, La..

A frequency curve for each of these four synthetic data sets for each site was computed following procedures outlined in U.S. Water Resources Council Bulletin 15 (1967). A weighted average of the four frequency curves was obtained for each site based on an isohyetal map of Mississippi and the site location. The average rainfall for the period of record used was 53 inches at Merdian, Miss., 51 inches at Vicksburg, Miss., 48 inches at Memphis, Tenn., and 62 inches at New Orleans, La.. The procedure was to determine the mean annual rainfall at each site from an isohyetal map of the state, then select the appropriate weighting of the discharges from the following formulas.

Sites having less than 51 inches Vicksburg, Miss. + Memphis, Tenn.

Sites having 51 to 53 inches

$\frac{\text { Meridian }+ \text { Vicksburg }}{2}$

Sites having 54 to 56 inches

$\frac{(2 x \text { Meridian })+\text { Vicksburg }+ \text { New Orleans, La. }}{4}$

Sites having 57 to 59 inches

$\frac{\text { Meridian }+ \text { Vicksburg }+(3 \times \text { New Orleans, La })}{5}$

Sites having greater than 59 inches New Orleans, La.

The discharge values of the $2,5,10,25,50$, and 100-year recurrence intervals from the log-Pearson Type III analyses were weighted using these formulas. For example, if the mean annual rainfall at a site was 52 inches, the average was used of the frequency values obtained from synthetic discharges generated by the Meridian and 


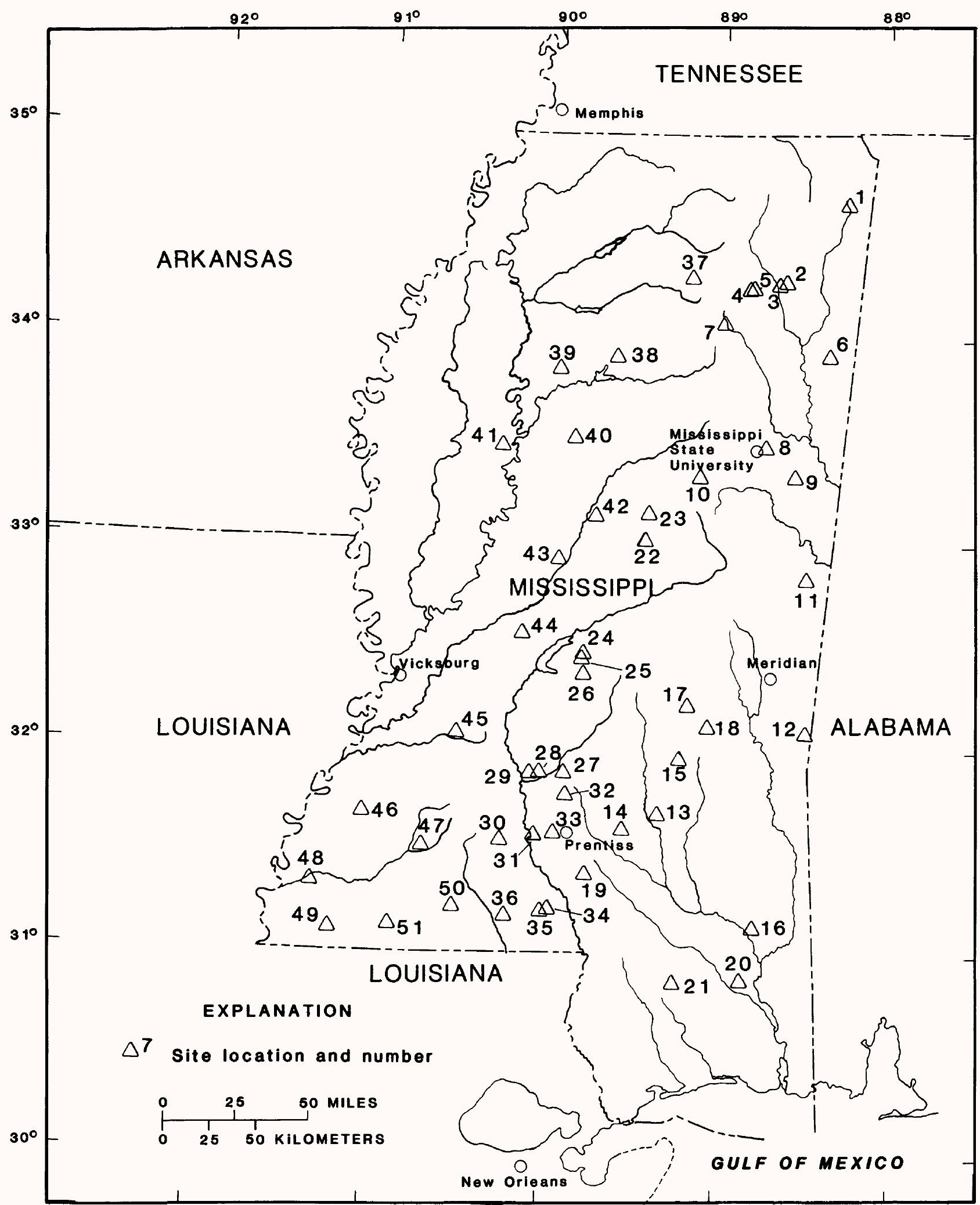

Figure 1.--Locations of gaging stations used for comparing observed and synthetic flood frequency. 
Vicksburg long term rainfall. Therefore the synthetic curves were usually a combination of more than one flood-frequency curve.

\section{ANALYSIS OF OBSERVED DATA}

Observed annual peak-flow data for 16 years or longer are available at 51 sites for which synthetic data were used in the 1976 floodfrequency report. The average length of record is just over 21 years and some of these sites now have 30 years of observed annual peak discharges. The site number, downstream order station number, period of record, and station name are given in table 1. The basin area of the sites ranges from 0.07 to $4.35 \mathrm{mi}^{2}$ (table 2). The channel length, in miles, was measured upstream from the site to the basin divide. The average slope, in feet per mile, was computed between points 10 and 85 percentile of the length upstream. These three basin parameters were found to be significant in regression analysis of flood magnitudes (Colson and Hudson, 1976).

The observed data were analyzed by fitting a Pearson Type III distribution to the logarithims of the annual peak discharges following procedures outlined in U.S. Water Resources Council Bulletin 17B, Guidelines for Determining Flood-Flow Frequencies" (1981). When logarithms of the discharges are used the distribution is usually referred to as a log-Pearson Type III distribution. The mean, standard deviation, and skew of the logarithms completely define the log-Pearson Type III distribution. Using these values from the observed data given in table 2 , the flood magnitude for any recurrence interval may be computed.

The synthetic data (Colson and Hudson, 1976) were analyzed in accordance with methodology described in Bulletin 15 of the U.S. Water Resources Council (1967). Both Bulletins 15 and 17B use a log-Pearson Type III distribution but differ in the weighting procedure for determining skew and the detection of outliers. Bulletin 15 did not weight the generalized skew and station skew as proposed in Bulletin 17B. Bulletin 17B recommends that the skew computed from the annual peaks be given a weight inversely proportional to the variance computed from the station data. No outliers were observed in plots of the synthetic data frequency curves.

High outliers were detected in 3 of the observed records and 1 low outlier was detected in each of 13 observed records. These were all treated according to procedures given in Bulletin 17B. Data for one station, Goines Draw near Prentiss, appears to be anomalous. The presence of five abnormally low annual peak discharges distorted the standard deviation. These low peak discharges were truncated by excluding peaks less than $20 \mathrm{ft} 3 / \mathrm{s}$ and the standard deviation was reduced from 0.603 to $0.445 \mathrm{log}$ units -- still considerably greater than the standard deviation of the other 50 sites.

\section{COMPARISON OF RESULTS}

The 2, 5, 10, 25, 50, and 100-year flood magnitudes are compared in table 2. For each site the discharges of the observed and synthetic 
Table 1.--Gaging stations and period of record

\begin{tabular}{|c|c|c|c|}
\hline $\begin{array}{l}\text { Site } \\
\text { number }\end{array}$ & $\begin{array}{l}\text { Station } \\
\text { number }\end{array}$ & Stream name and location & $\begin{array}{c}\text { Perlod of } \\
\text { Record }\end{array}$ \\
\hline $\begin{array}{l}1 \\
2 \\
3 \\
4 \\
5\end{array}$ & $\begin{array}{l}02429980 \\
02435300 \\
02435400 \\
02435920 \\
02435930\end{array}$ & $\begin{array}{l}\text { Pollard Mill Creek near Paden } \\
\text { Cow Pike Pass near Tupelo } \\
\text { Clear Branch near Tupelo } \\
\text { Cotton Gin Branch near Tupelo } \\
\text { Shell Creek near Tupelo }\end{array}$ & $\begin{array}{l}1967-84 \\
1955-77 \\
1955-83 \\
1955-76 \\
1955-84\end{array}$ \\
\hline $\begin{array}{r}6 \\
7 \\
8 \\
9 \\
10\end{array}$ & $\begin{array}{l}02437550 \\
02439800 \\
02441220 \\
02443700 \\
02447220\end{array}$ & $\begin{array}{l}\text { Nichols Creek at Quincy } \\
\text { Cowbell Creek near Houlka } \\
\text { Sand Creek Tributary near Mayhew } \\
\text { Cedar Creek near Brooksville } \\
\text { Bogue Fallah Creek Tributary near Ackerman }\end{array}$ & $\begin{array}{l}1966-84 \\
1955-76 \\
1966-84 \\
1965-84 \\
1966-83\end{array}$ \\
\hline $\begin{array}{l}11 \\
12 \\
13 \\
14 \\
15\end{array}$ & $\begin{array}{l}02448620 \\
02469672 \\
02472160 \\
02472810 \\
02473850\end{array}$ & $\begin{array}{l}\text { Flat Scooba Creek Tributary near Scooba } \\
\text { Little Okatuppa Creek near Quitman } \\
\text { Big Creek near Laurel } \\
\text { Okatoma Creek Tributary near Collins } \\
\text { Tallahoma Creek Tributary at Lake Como }\end{array}$ & $\begin{array}{l}1967-84 \\
1966-84 \\
1966-84 \\
1967-84 \\
1964-84\end{array}$ \\
\hline $\begin{array}{l}16 \\
17 \\
18 \\
19 \\
20\end{array}$ & $\begin{array}{l}02475050 \\
02477050 \\
02477090 \\
02478600 \\
02479165\end{array}$ & $\begin{array}{l}\text { Waterfall Branch near Mdain } \\
\text { Souinlovey Creek near Baxter } \\
\text { Powers Creek near Rose Hill } \\
\text { Granny Branch at Piave } \\
\text { Mosquito Branch at Benndale }\end{array}$ & $\begin{array}{l}1955-84 \\
1964-84 \\
1964-84 \\
1967-84 \\
1955-77\end{array}$ \\
\hline $\begin{array}{l}21 \\
22 \\
23 \\
24 \\
25\end{array}$ & $\begin{array}{l}02479187 \\
02482310 \\
02483890 \\
02484750 \\
02485380\end{array}$ & $\begin{array}{l}\text { Red Creek Tributary near Wiggins } \\
\text { Lobutcha Creek Tributary at Wamba } \\
\text { Yockanookany River Tributary near McCool } \\
\text { Red Cane Creek Tributary near Pisgah } \\
\text { Hollybush Creek Tributary No. I near Pisgah }\end{array}$ & $\begin{array}{l}1966-84 \\
1964-84 \\
1965-84 \\
1965-84 \\
1965-84\end{array}$ \\
\hline $\begin{array}{l}26 \\
27 \\
28 \\
29 \\
30\end{array}$ & $\begin{array}{l}02485392 \\
02487670 \\
02487710 \\
02487770 \\
02488340\end{array}$ & $\begin{array}{l}\text { Clear Creek Tributary near Pelahatchie } \\
\text { Boggans Ditch near Mendenhall } \\
\text { Barrets Branch near Pinola } \\
\text { Bradleys Ditch near Pinola } \\
\text { Small Pine Ditch near Monticello }\end{array}$ & $\begin{array}{l}1965-84 \\
1955-84 \\
1955-77 \\
1955-77 \\
1955-84\end{array}$ \\
\hline $\begin{array}{l}31 \\
32 \\
33 \\
34 \\
35\end{array}$ & $\begin{array}{l}02488510 \\
02488550 \\
02488680 \\
02489030 \\
02489160\end{array}$ & $\begin{array}{l}\text { Roadside Park Ditch near Monticello } \\
\text { Goines Draw near Prentiss } \\
\text { Plum Ditch near Prentiss } \\
\text { Elmers Draw near Columbia } \\
\text { Kokomo Draw at Kokomo }\end{array}$ & $\begin{array}{l}1955-77 \\
1955-84 \\
1955-76 \\
1955-84 \\
1955-77\end{array}$ \\
\hline $\begin{array}{l}36 \\
37 \\
38 \\
39 \\
40\end{array}$ & $\begin{array}{l}02490550 \\
07267200 \\
07283490 \\
07285700 \\
07286520\end{array}$ & $\begin{array}{l}\text { Middle Fork Hickory Flat near Tylertown } \\
\text { Cracker Ditch near Pontotoc } \\
\text { Caney Creek near Coffeeville } \\
\text { Long Creek near Cascilla } \\
\text { Big Sand Creek Tributary near Carrollton }\end{array}$ & $\begin{array}{l}1953-84 \\
1955-75 \\
1955-84 \\
1965-84 \\
1965-84\end{array}$ \\
\hline $\begin{array}{l}41 \\
42 \\
43 \\
44 \\
45\end{array}$ & $\begin{array}{l}07287170 \\
07289395 \\
07289470 \\
07289641 \\
07290525\end{array}$ & $\begin{array}{l}\text { Mosquito Creek Tributary No. } 2 \text { at Itta Bena } \\
\text { Sharkey Creek Tributary near West } \\
\text { Tacketts Creek Tributary near Plckens } \\
\text { Panther Creek Tributary near Flora } \\
\text { White Oak Creek Tributary near Utica }\end{array}$ & $\begin{array}{l}1966-84 \\
1967-84 \\
1965-84 \\
1964-84 \\
1965-84\end{array}$ \\
\hline $\begin{array}{l}46 \\
47 \\
48 \\
49 \\
50 \\
51\end{array}$ & $\begin{array}{l}07290830 \\
07291260 \\
07294400 \\
07373550 \\
07375235 \\
07376760\end{array}$ & $\begin{array}{l}\text { Little Creek near Fayette } \\
\text { Beaver Run near McCall Creek } \\
\text { Observers Draw near Coloroso } \\
\text { Moores Branch near Woodville } \\
\text { Tangipahoa River Tributary near McComb } \\
\text { CRS Draw near LIberty }\end{array}$ & $\begin{array}{l}1967-84 \\
1955-77 \\
1954-76 \\
1965-84 \\
1966-84 \\
1955-84\end{array}$ \\
\hline
\end{tabular}




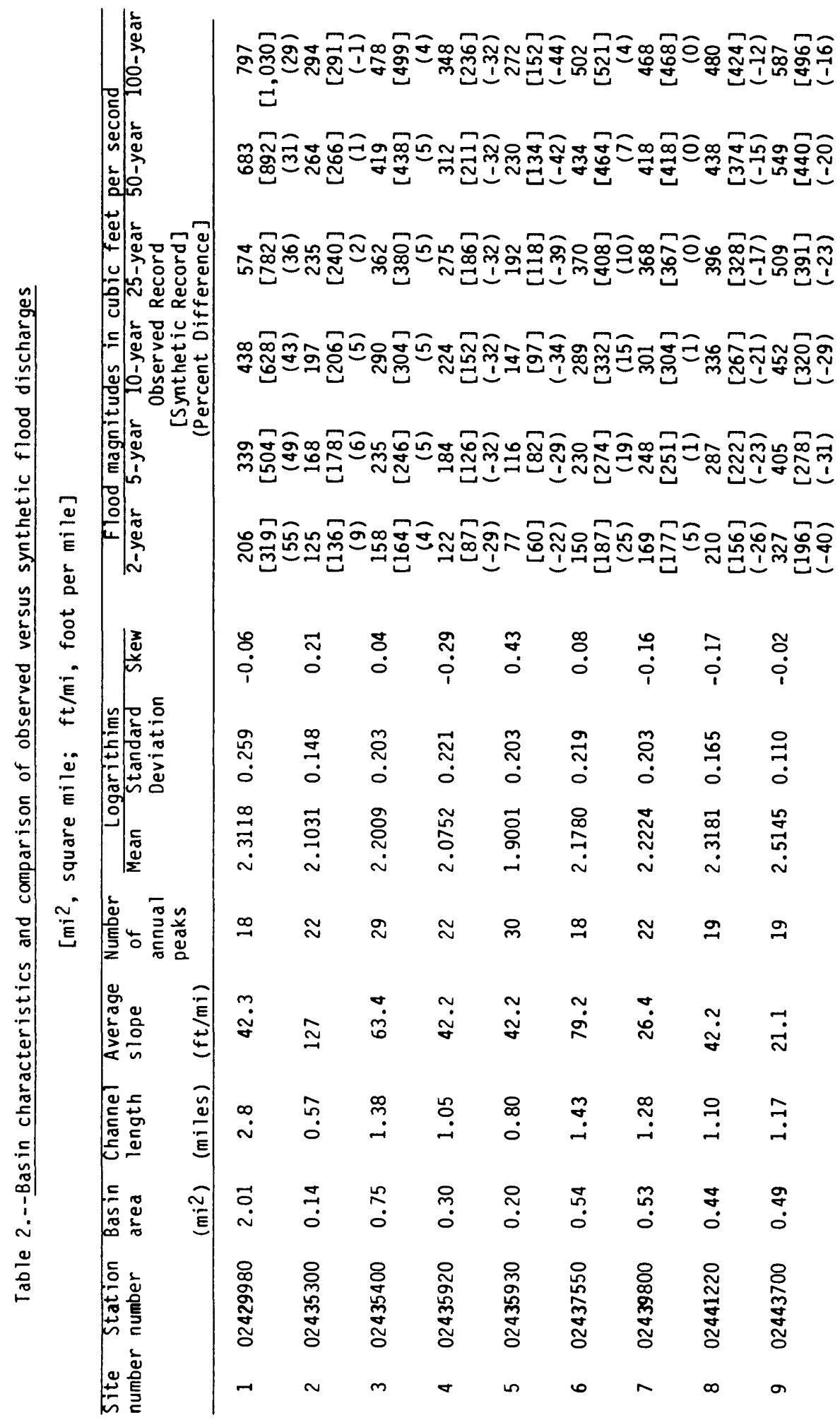




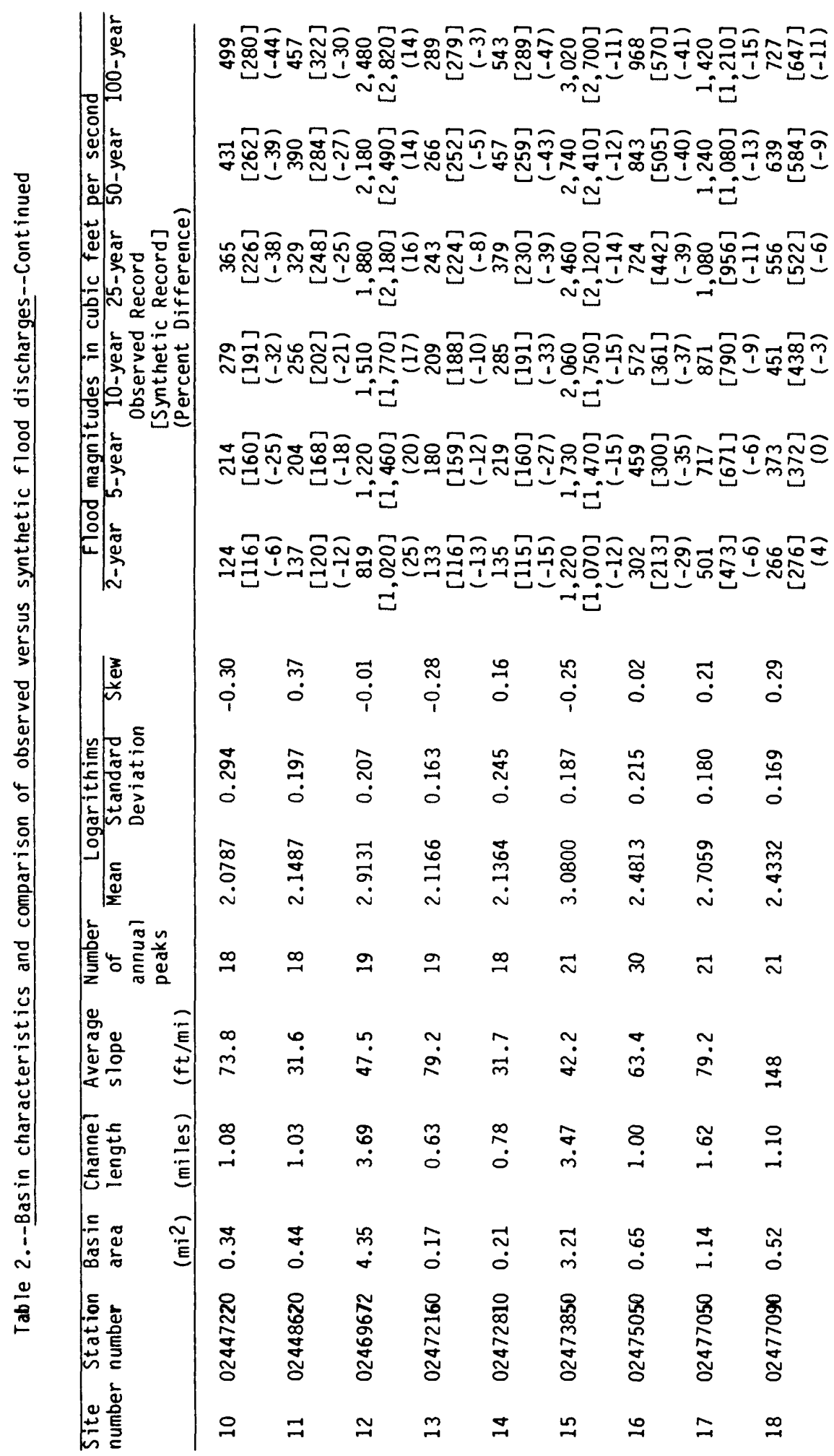




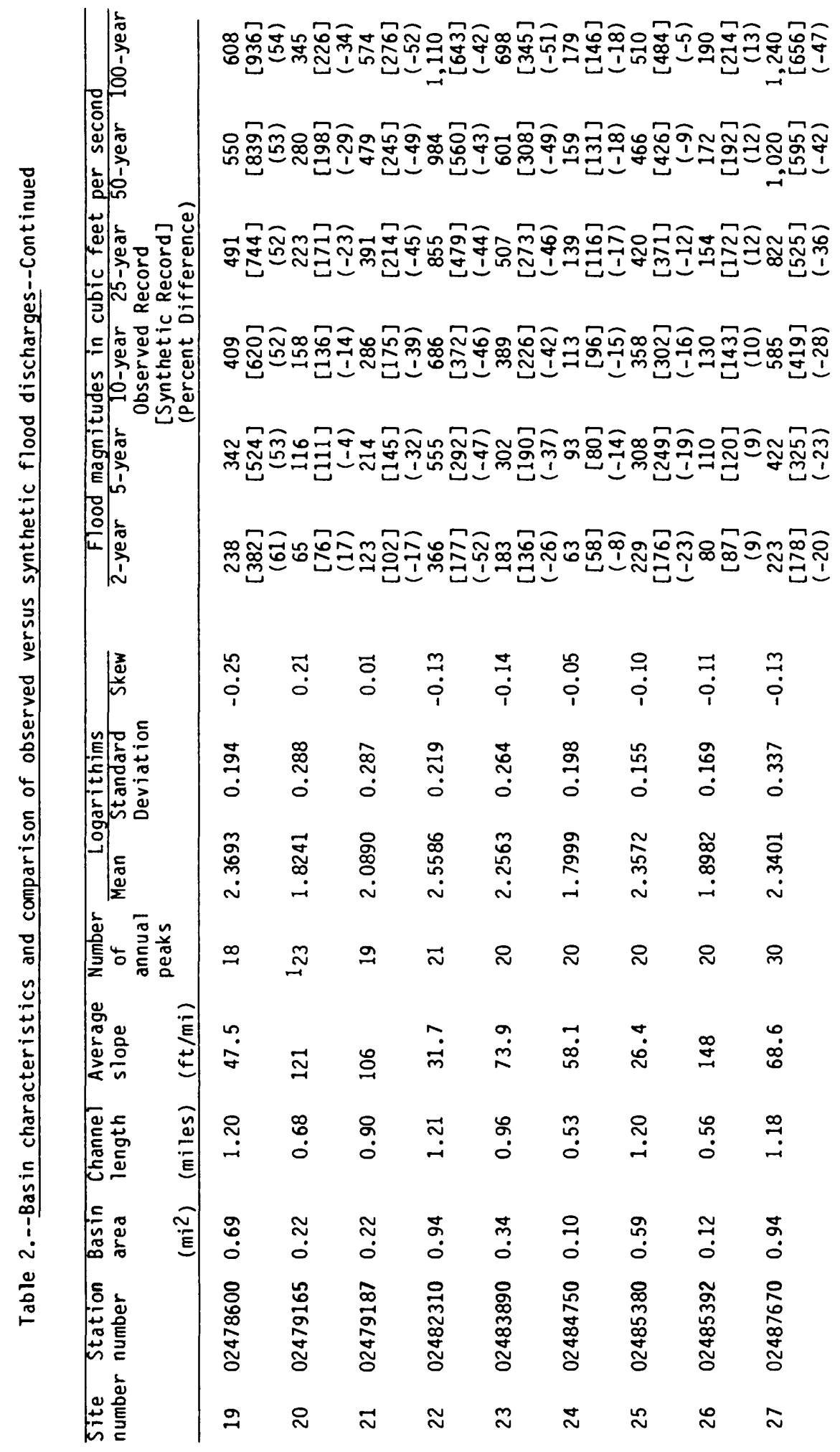




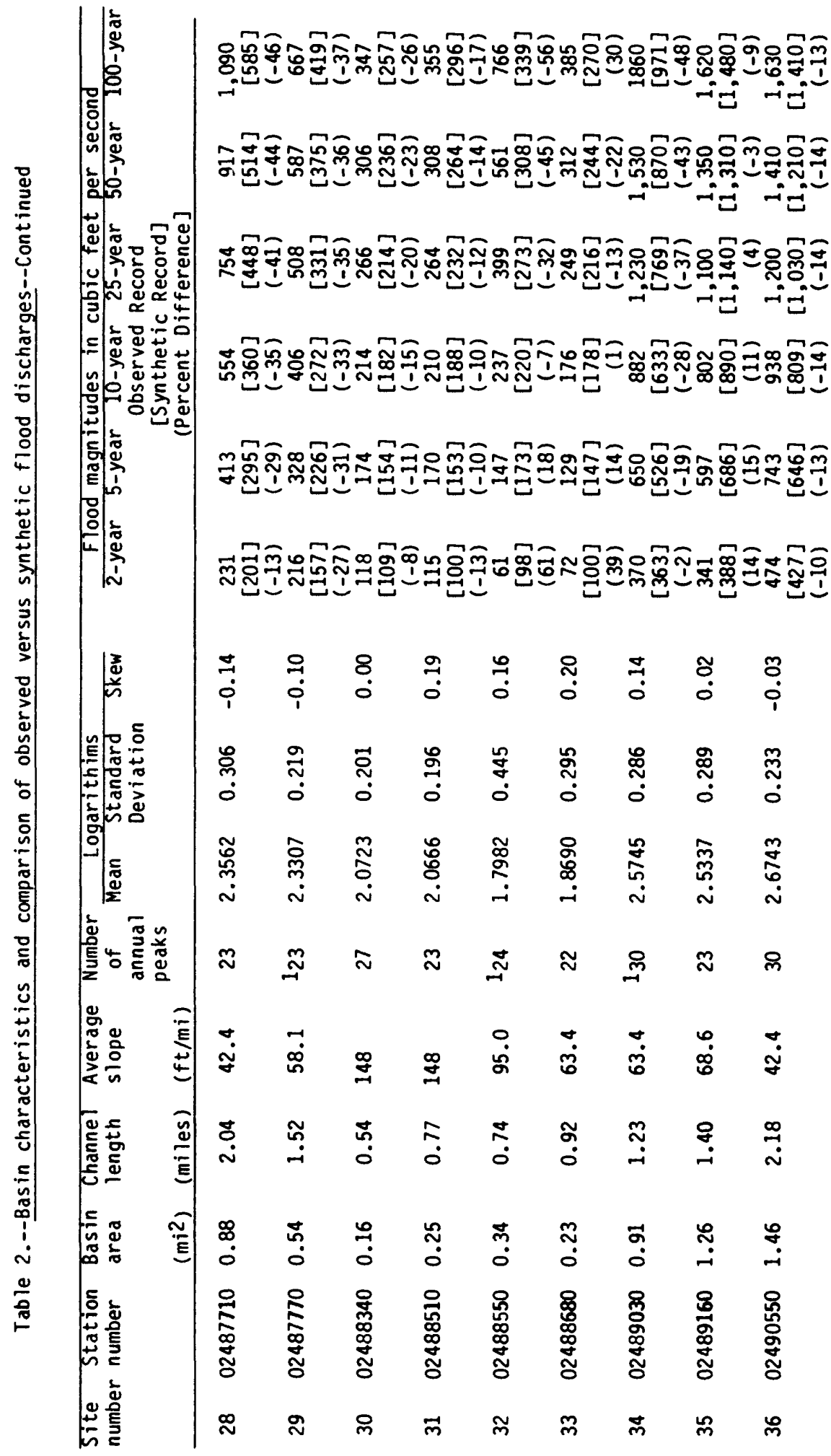




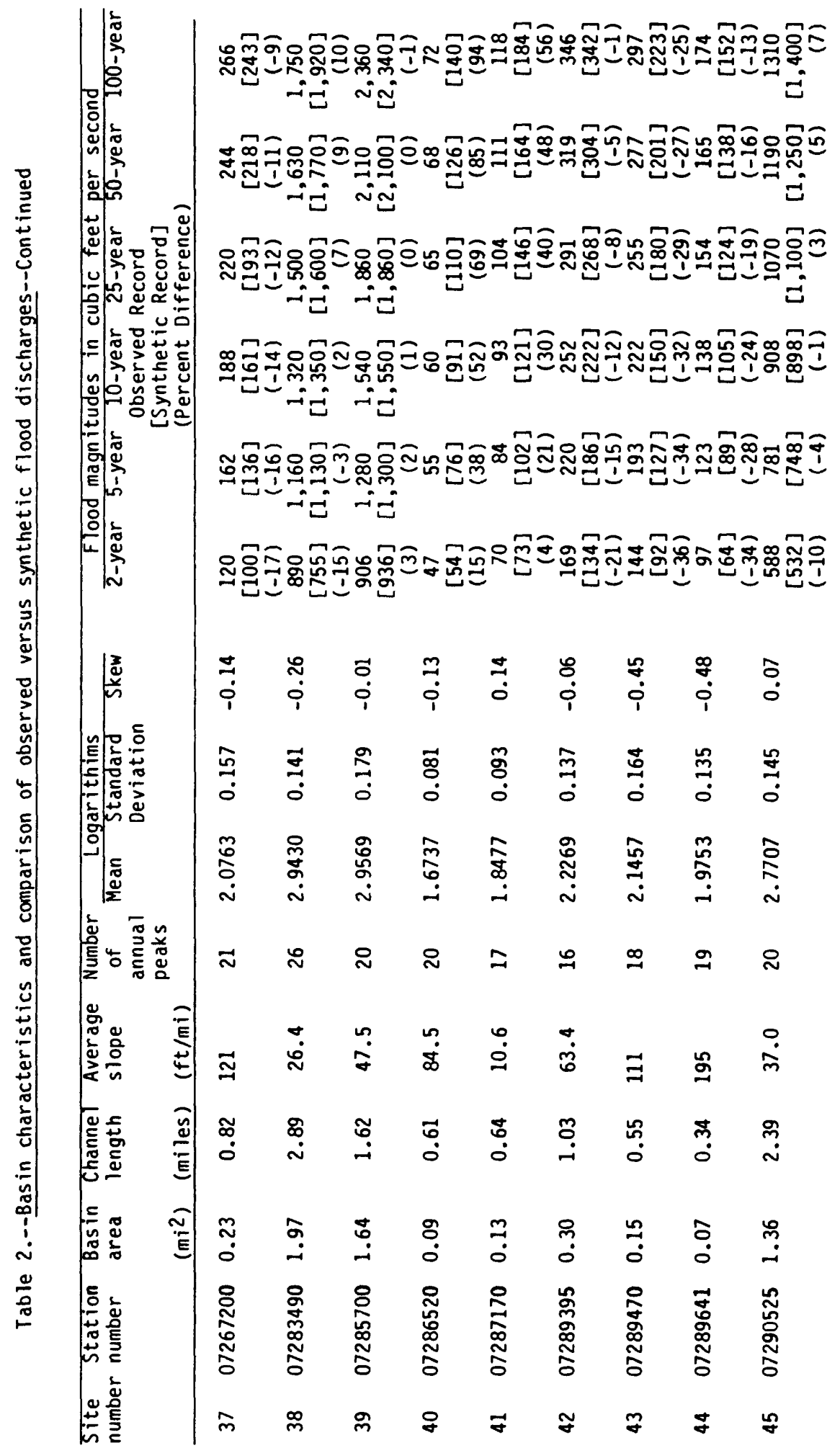




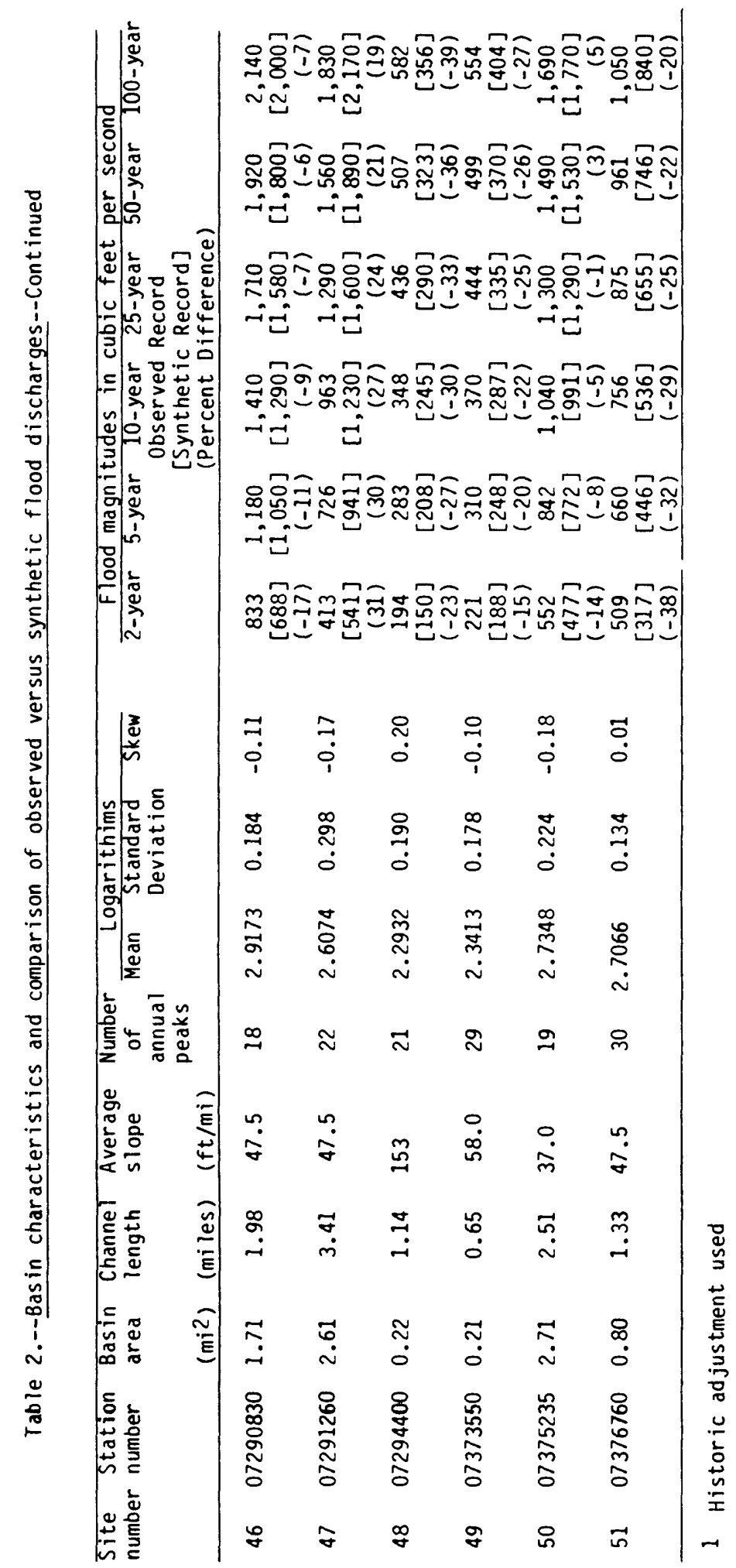


floods are given, followed by the difference expressed as a percent of the observed discharge for each recurrence interval.

One of the most effective ways to compare results is by graphical plots. Figures 2 through 7 show the synthetic results versus those obtained from observed data for the $2,5,10,25,50$, and 100-year flood discharges, respectively. A visual inspection indicates that in general there is good agreement between the synthetic and observed results.

A closer study indicates that values computed from the observed record tend to be slightly greater than values obtained from the synthetic record. For statistical analysis the data were transformed by taking the logarithms of the observed and synthetic discharge values. The RMSE (root mean square error) and the mean of the residuals (observed-synthetic estimate) were computed for the 2, 5, 10, 25, 50, and 100-year recurrence interval floods. The results, expressed as a percent of the observed data value, show that the average RMSE ranges from 27 to 38 percent and the average difference from -9 to -18 percent at the 2 and 100-year recurrence intervals respectively. The Student's $t$ statistic was computed from the residuals for each of the recurrence interval. The value of Student's $t$ ranged from -2.56 to -4.26 which at the 5 percent significance level indicate that the synthetic results are significantly different from the observed results for all recurrence intervals.

$\begin{array}{lcccccc}\begin{array}{l}\text { Recurrence } \\ \text { Interval }\end{array} & \text { 2-year } & 5 \text {-year } & \text { 10-year } & 25 \text {-year } & 50 \text {-year } & 100 \text {-year } \\ \begin{array}{l}\text { RMS difference } \\ \text { in percent }\end{array} & 27 & 27 & 28 & 32 & 35 & 38 \\ \begin{array}{l}\text { Average differ- } \\ \begin{array}{l}\text { ence in per- } \\ \text { cent (BIAS) }\end{array}\end{array} & -9 & -11 & -13 & -15 & -16 & -18\end{array}$

The flood-frequency curves for the 51 sites are shown in figures 8 and 9. Figure 8 shows the curves based on observed data. Many of these curves cross, indicating a marked difference in slope among the frequency curves. The extremely steep curve depicts the anomalous data for Goines Draw near Prentiss. Comparing the synthetic frequency curves shown in figure 9, fewer of the curves cross, indicating less variation in slope. Both sets of frequency curves span about the same range of discharges but the observed data curves exhibit a slightly wider variation.

The reduced variance in the synthetic results is partially due to model limitations. Many basin parameters were averaged or lumped into the model. Only four sets of long-term rainfall records were available to generate the synthetic flood peaks. The rainfall was implicitly distributed over the basin in the same manner as for the storms used in calibration of the model. 


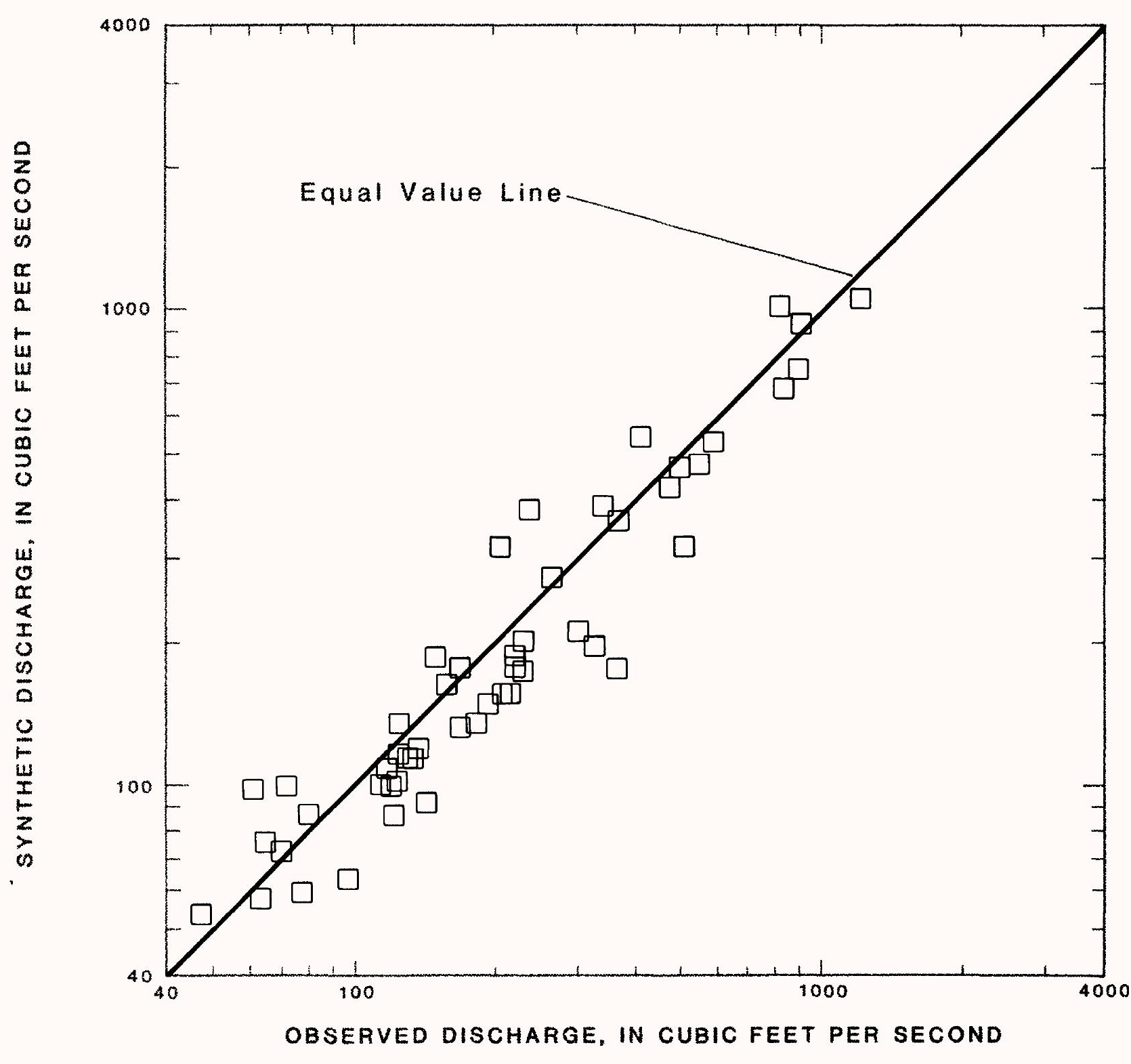

Figure 2.--Comparison of synthetic and observed 2-year flood discharge. 


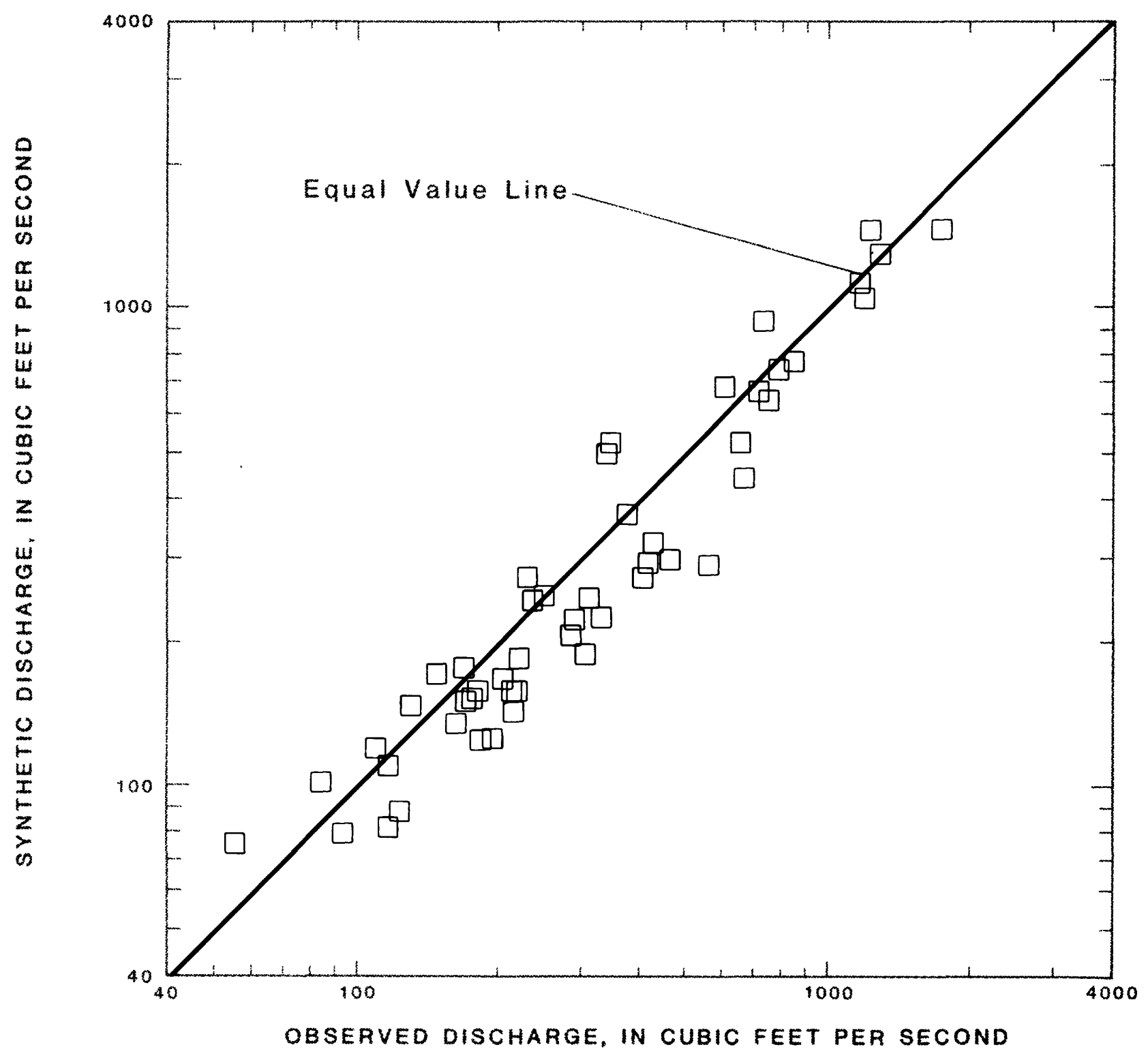

Figure 3.--Comparison of synthetic and observed 5-year flood discharge. 


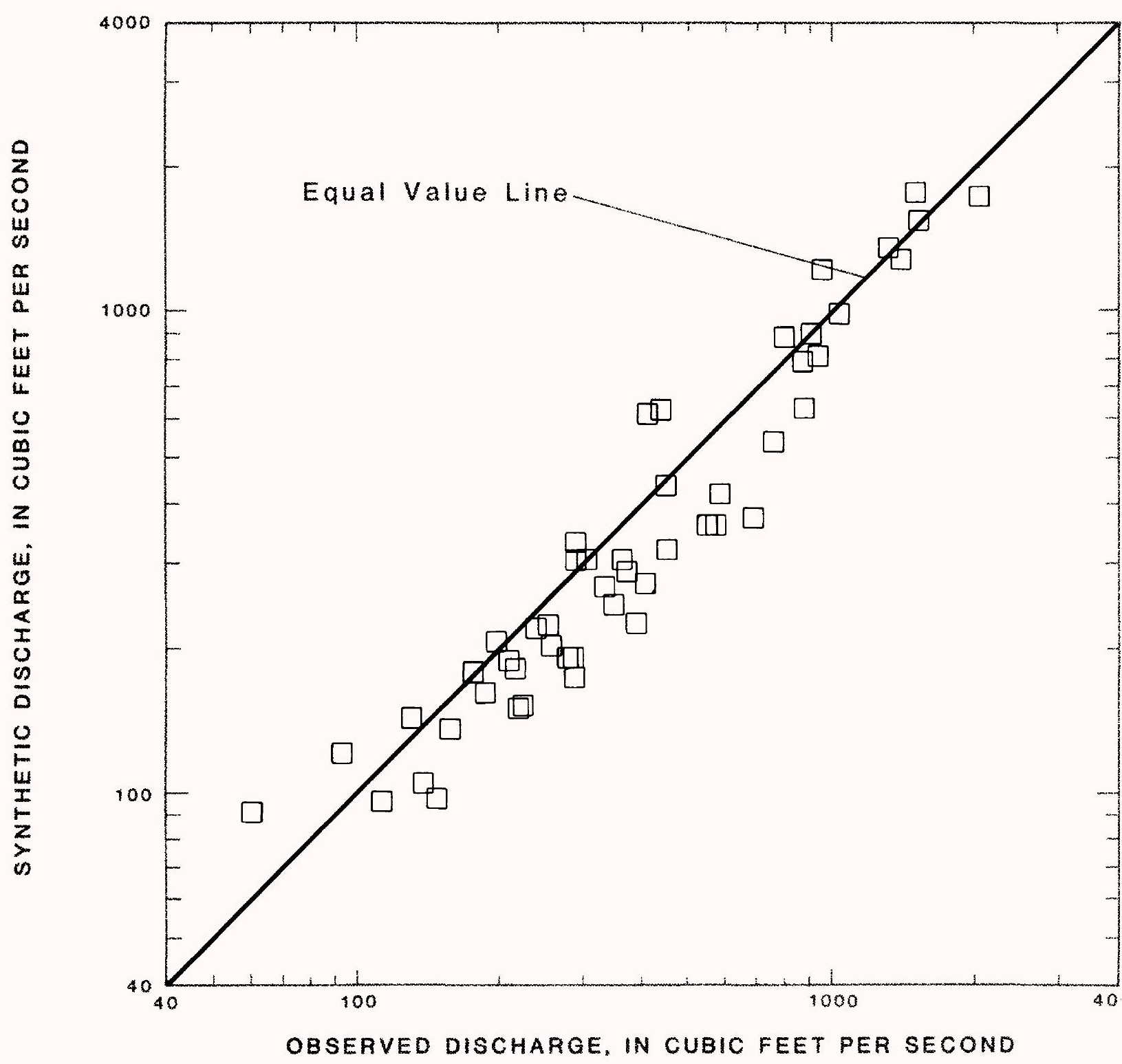

Figure 4.--Comparison of synthetic and observed 10-year flood discharge. 


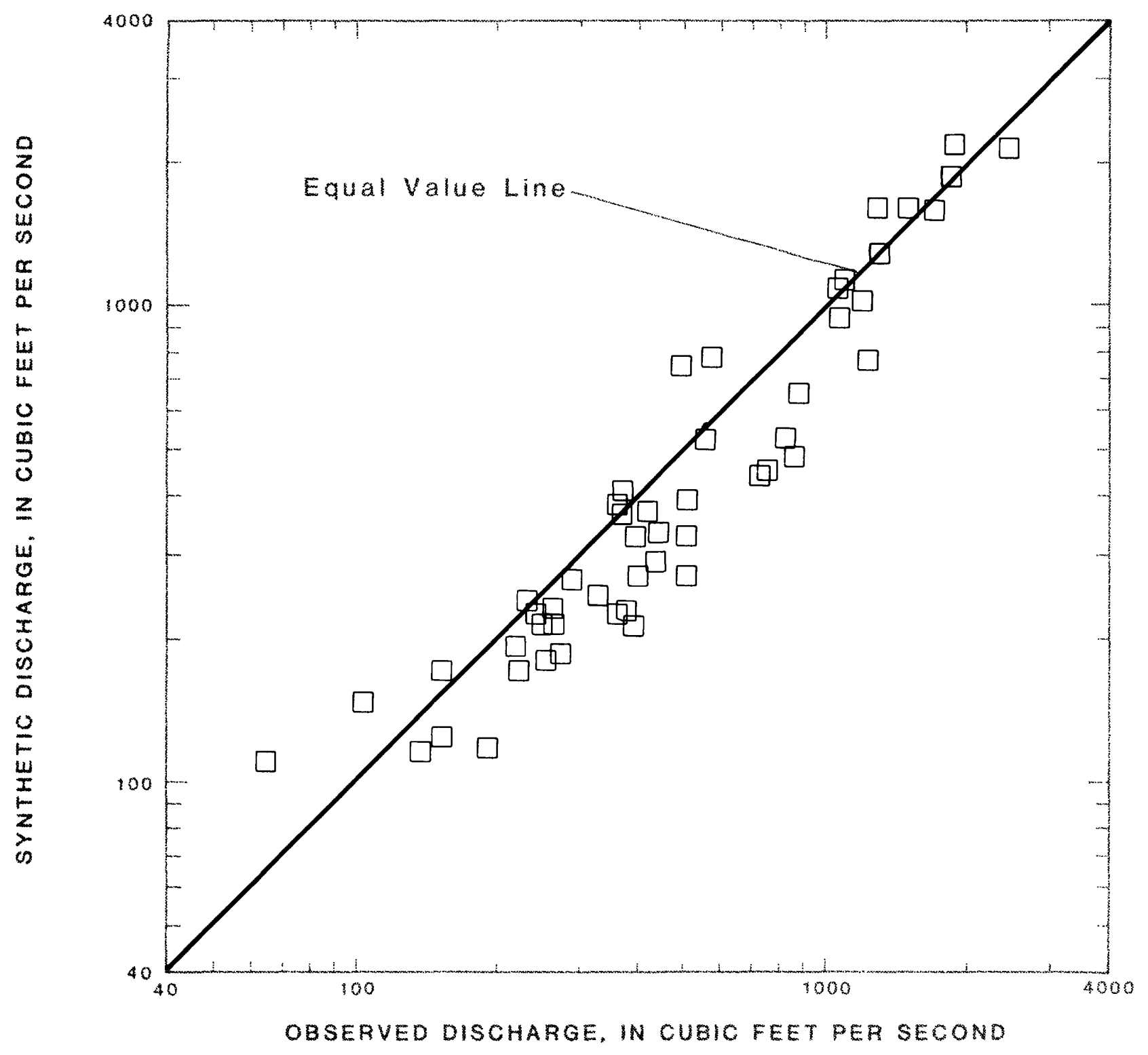

Figure 5.--Comparison of synthetic and observed 25-year flood discharge. 


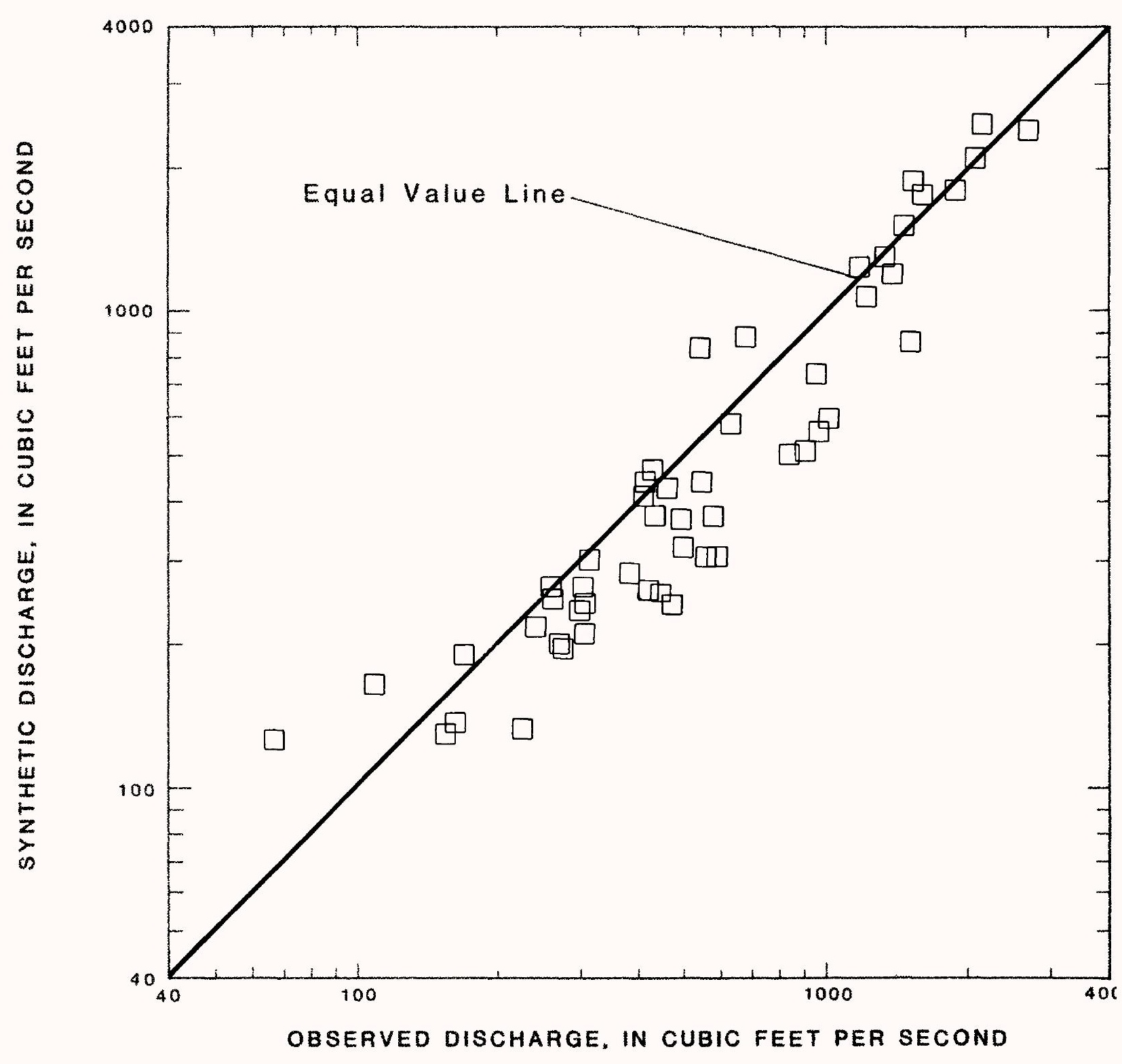

Figure 6.--Comparison of synthetic and observed 50-year flood discharge. 


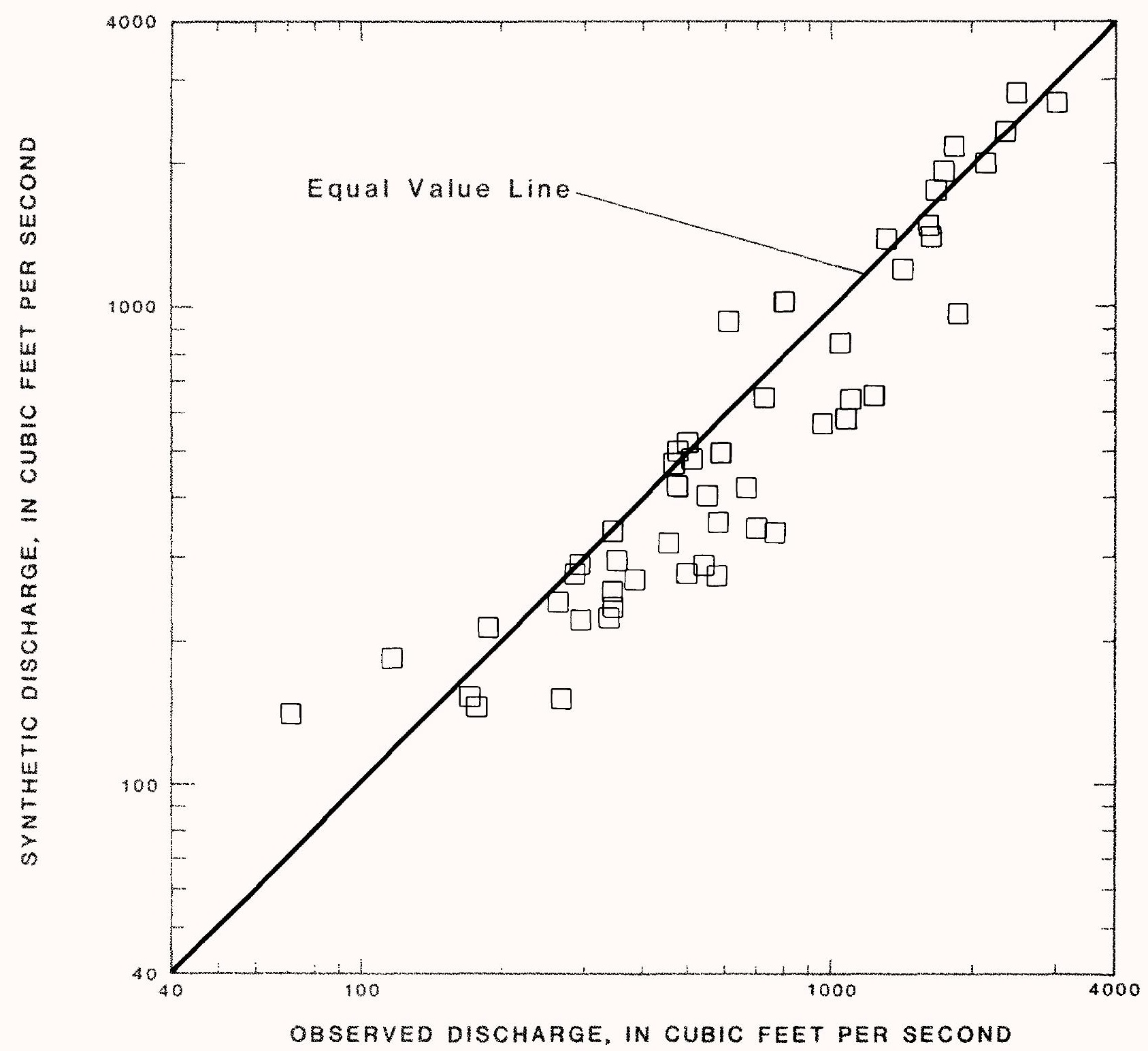

Figure 7.--Comparison of synthetic and observed 100-year flood discharge. 


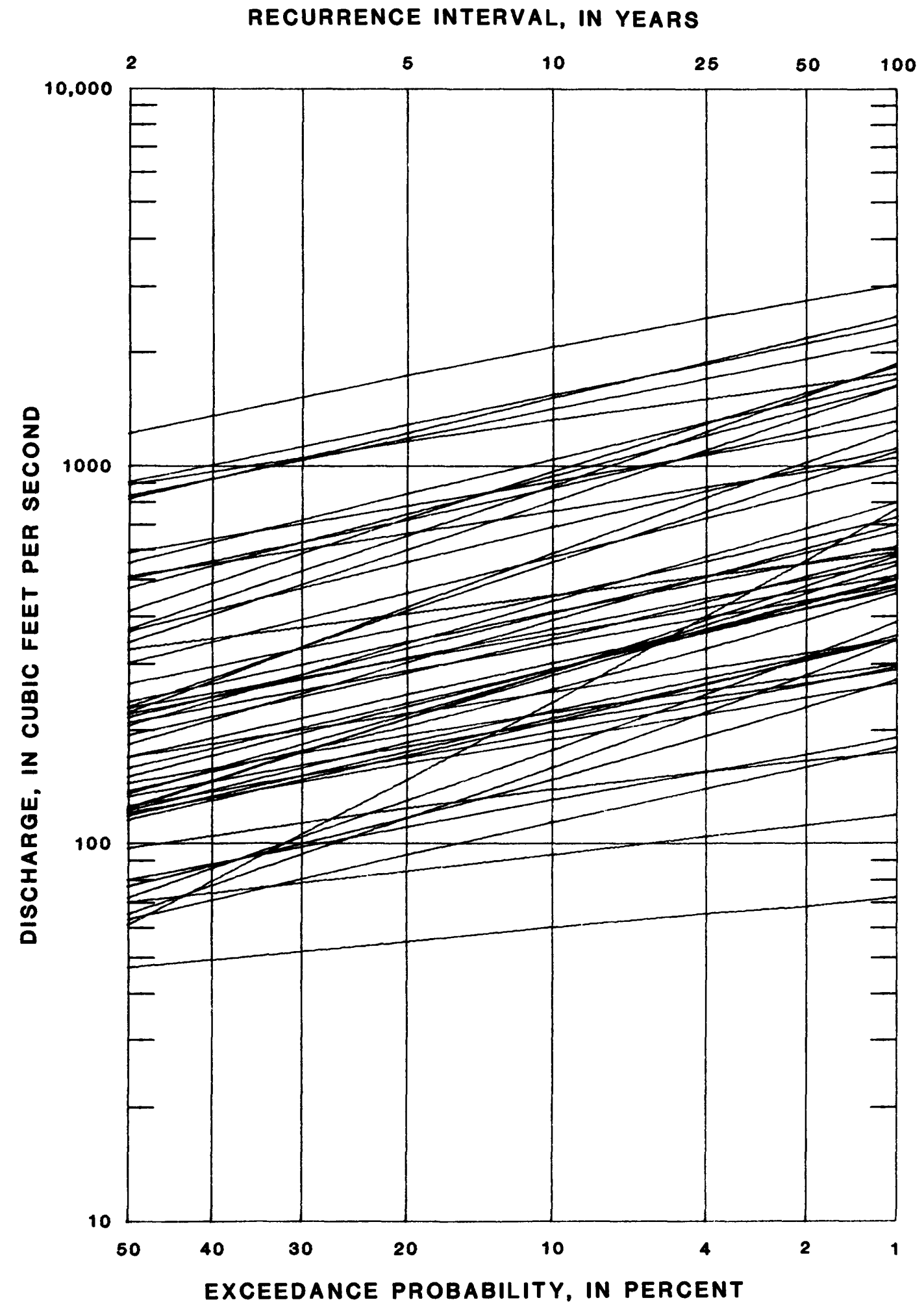

Figure 8.--Flood frequency curves for selected gaging stations based on observed (measured) discharge data. 
RECURRENCE INTERVAL, IN YEARS

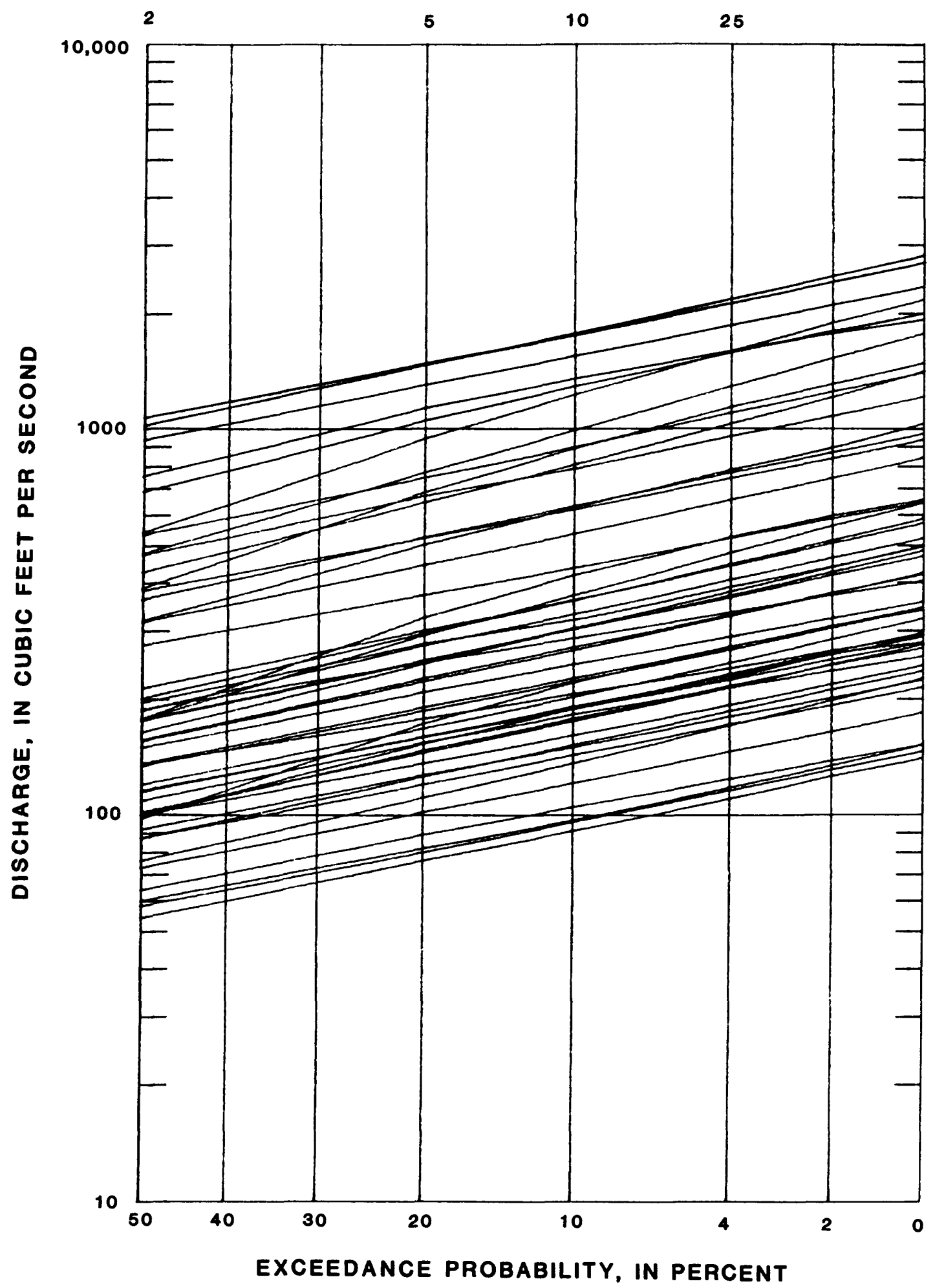

Figure 9.--Flood frequency curves for selected gaging stations based on synthetic discharge data. 
The greater variance in the frequency curves that were based on observed data (fig. 8) is due partly to shorter record length as well as the increased freedom for variation in basin characteristics that affect the distributions of flood peaks. Benson (1952) showed that within a known homogeneous record that the random error for the 100-year flood could range from about 30 percent less than to more than 50 percent greater than the true frequency curve when based on 25 years of annual peaks.

Benson concluded that accuracy within 10 percent is rarely attainable and that accuracy within 25 percent should be considered satisfactory. Considering the greater variation that is to be expected from the relatively short length (21 years) of observed record, the 27 to 38 percent RMS difference between the synthetic record (67 years) is considered to be a satisfactory agreement.

\section{SUMMARY}

The immediate need for flood-frequency information on small drainage areas led the U.S. Geological Survey to synthesize flood peaks using a rainfall driven digital model. An average of 21 years of annual peaks have been collected for 51 sites in Mississippi for which synthetic records were developed. The synthetic records were analyzed using techniques described in Bulletin 15 of the Water Resources Council. These results are those used in the report "Flood Frequency of Mississippi Streams" (Colson and Hudson 1976). The observed annual peaks were analyzed under guidelines presented in Bulletin 17B of the Water Resources Councii.

The differences for each of the 2, 5, 10, 25, 50, and 100-year recurrence-interval floods are evaluated. The average difference ranged from -9 to -18 percent. Plots of each of the synthetic versus the observed discharges were prepared for each of the selected recurrenceinterval floods. The least squares fit-line on these graphs indicated slightly better agreement at the lower discharges. Plots of the entire frequency curve for each of the 51 sites indicated more variation among frequency curves based on observed record than for the synthetic record. This is as expected due to the averaging effect of the model on the synthetic data and the longer record. The difference from the observed record is about the same as might be expected for 21 years of record. The results are considered satisfactory. 


\section{SELECTED REFERENCES}

Benson, M. A., 1952, Characteristic of frequency curves based on theoretical 1,000-year record: U.S. Geological Survey Open-File Report, $21 \mathrm{p}$.

-----1962, Factors influencing the occurrence of floods in a humid region of diverse terrain: U.S. Geological Survey Water Supply Paper 1580-B, $64 \mathrm{p}$.

Colson, B. E., and Hudson, J. W., 1976, Flood frequency of Mississippi streams, Mississippi State Highway Department Report No. 76-014-PR, $34 \mathrm{p}$.

Dawdy, D. R., Lichty, R. W., and Bergman, J. M., 1972, A rainfall-runoff simulation model for estimation of flood peaks for small drainage basins: U.S. Geological Survey Professional Paper 506-B, 28 p.

Hardison, C. H., 1971, Prediction error of regression estimates of streamflow characteristics at ungaged sites: U.S. Geological Survey Professional Paper 750-C, p. 228-236.

Maddock, Thomas, III, 1974, An optimum reduction of gauges to meet data program constraints: Bulletin, International Association Hydrologic Sciences, v. 19, no. 3, p. 337-345.

Matalas, N. C., 1967, Optimum gaging station location: Proceedings IBM Scientific Computing Symposium on Water and Air Resource Management, October 23-25, 1967, Yorktown Heights, New York, p. 85-94.

Moss, M. E., and Karlinger, M. R., 1974, Surface-water network design by regression analysis simulation: Water Resources Research, v. 10, no. 3, p. 427-433.

Riggs, H. C., 1968b, Frequency curves: U.S. Geological Survey Techniques of Water Resources Investigations, book 4, chapter Al, 39 p.

U.S. Water Resources Council, 1967, A uniform technique for determining flood-flow frequencies: U.S. Water Resources Council Bulletin 15, $15 \mathrm{p}$.

U.S. Water Resources Council, 1981, Guidelines for determining floodflow frequency, Bulletin 17B, $28 \mathrm{p}$. 